\title{
IDENTIFIKASI EKTOPARASIT PADA IKAN KAPAR (Belontia hasselti) YANG DIPELIHARA DI KOLAM TERPAL
}

\author{
(Identification of Ectoparacites in Kapar Fish (Belontia hasselti) Reared in Plastic Lined Pond) \\ Frid Agustinus dan Gusliany \\ Program Studi Budidaya Perairan Fakultas Perikanan Universitas Kristen Palangka Raya \\ Jalan RTA. Milono Km. 8,5 Palangka Raya 73112 \\ Email: soewarno50@yahoo.com
}

Article Submitted : 18-04-2020

Article Accepted : 29-05-2020

\begin{abstract}
This study aims to identify ectoparasites in Kapar fish (Belontia hasselti) in plastic lined pond. This research was conducted by taking samples of Kapar fish that experienced symptoms of disease in plastic lined pond. Identification of ectoparasites in fish is done in the laboratory. As a comparison, sampling of Kapar fish in the Sebangau river where the fish origin was taken is to see if there is innate ectoparasites from river. The results showed that ectoparasites were found in fish gills. The types of ectoparasites obtained were 3 ectoparasites including Dactylogyrus sp., Myxobolus sp., Vorticella sp. However, ectoparasites that attack Kapar fish are more dominant species of Dactylogyrus sp. The range of temperature and $\mathrm{pH}$ is still normal for the life of a Kapar fish. But the DO (Dissolved Oxygen) range in plastic lined pond is lower which is around $3 \mathrm{mg} / \mathrm{l}$ compared to the Sebangau river which is around $4 \mathrm{mg} / \mathrm{l}$ although there is additional aeration, this is likely to cause fish stress.
\end{abstract}

Keywords : identification, ectoparacite, kapar fish

\section{PENDAHULUAN}

Sungai Sebangau merupakan salah satu sungai besar di Kalimantan Tengah dengan panjang 198,5 km. Sungai Sebangau memiliki karakteristik sebagai sungai bergambut, karena air sungai berasal dari hutan rawa gambut. Air yang mengandung gambut yang tinggi dialirkan dari hutan rawa gambut tersebut (Haraguchi, 2007). Airnya berwarna coklat jernih yang bersifat

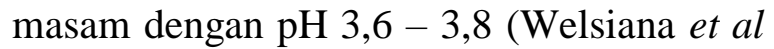
., 2012).

Keanekaragaman ikan yang menghuni perairan gambut di sungai Sebangau salah satunya adalah ikan Kapar (Belontia hasselti). Ikan Kapar ini tergolong pada family Belontiidae yang memiliki nama ilmiah Belontia hasselti. Ikan Kapar biasa dikonsumsi secara lokal dan juga diperdagangkan. Ikan ini juga dikenal dengan bermacam-macam nama di setiap daerah, contohnya: Kapar (Kalimantan), Kumpang atau Ketoprak (Kalbar), Selincah (Sumatera) (Daulay et al., 2018; Hasanah et al., 2019). Ikan kapar ini juga memiliki nilai ekonomis, biasanya dipasaran ikan ini dijual dengan harga Rp.20.000. - 30.000/Kg. Sementara itu ikan kapar juga bisa ditemukan hanya pada musim-musim tertentu saja.

Selama ini khususnya di Kalimantan Tengah, ikan Kapar yang dikonsumsi masih mengandalkan penangkapan dari alam dan belum ada yang membudidayakannya. Penelitian mengenai ikan ini masih sedikit 
dan hanya dalam tahap awal budidaya (Daulay et al., 2018; Hasanah et al., 2019) terlebih belum adanya penelitian mengenai ektoparasit yang menyerang ikan lokal ini. Ektoparasit merupakan salah satu penyakit yang biasa ditemukan pada kegiatan domestikasi yang merupakan langkah awal untuk kegiatan budidaya ikan lokal. Penyesuaian terhadap lingkungan budidaya menyebabkan tingkat stress yang tinggi pada ikan liar sehingga memudahkan ikan terserang penyakit. Infeksi ektoparasit dapat menjadi salah satu faktor predisposisi bagi infeksi organisme patogen yang lebih berbahaya seperi virus dan bakteri. Kerugian non letal lain dapat berupa kerusakan organ luar yaitu kulit dan insang (Kadarsah et al., 2017). Pada beberapa minggu masa adaptasi pemeliharan ikan Kapar yang kami lakukan di kolam terpal menunjukkan permukaan tubuh ikan berwarna putih-putih mirip seperti kapas. Ektoparasit merupakan masalah klasik yang merugikan, namun belum mendapatkan perhatian yang baik (Salam \& Hidayati, 2017). Pengetahuan mengenai ektoparasit dan ciri-ciri ikan terserang perlu diketahui untuk upaya pencegahan dan pengendaliannya.

\section{METODE PENELITIAN}

\section{Waktu dan Tempat}

Penelitian ini dilaksanakan pada tanggal 23 Juli - 23 Agustus 2019 di kolam terpal yang merupakan tempat ikan Kapar yang diduga terkena penyakit. Identifikasi ektoparasit sampel ikan dilakukan di Laboratorium Stasiun Karantina Ikan, Pengendalian Mutu Dan Keamanan Hasil Perikanan Kelas 1 Palangka Raya, Kalimantan Tengah.

\section{Alat dan Bahan}

Alat yang digunakan antara lain dissecting set, gunting, pinset, timbangan penggaris, mikroskop, pipet tetes, cover glass, jarum preparat, objek glass, preparat, nampan, kamera. Bahan yang digunakan antara lain sampel ikan uji dan air, buku identifikasi parasite, aquades, tisu, lugol, $\mathrm{NaCl}$.

\section{Pelaksanaan Penelitian}

Penelitian ini dilakukan dengan pengambilan sampel ikan Kapar yang mengalami gejala penyakit di kolam terpal. Sumber air kolam budidaya ikan tersebut dari sumur bor. Identifikasi ektoparasit pada ikan dilakukan di laboratorium. Sebagai pembanding juga dilakukan pengambilan sampel ikan Kapar di sungai Sebangau untuk melihat apakah ada ektoparasit bawaan dari alam.

\section{Identifikasi Ektoparasit dari Sampel Ikan}

Pemeriksaan yang dilakukan meliputi bagian luar ikan. Pemeriksaan ektoparasit dilakukan dengan cara mengamati tanda-tanda luar pada permukaan tubuh (lendir), insang, sirip ekor ikan untuk menentukan keberadaan parasit pada ikan tersebut. Kemudian, proses pengambilan lendir pada tubuh ikan dilakukan dengan cara dikerok pada permukaan tubuh ikan, meletakkan di atas objek glass dan ditetesi dengan aquades dan $\mathrm{NaCl}$, kemudian ditutup dengan cover glass dan selanjutnya diamati dibawah mikroskop. Pengamatan pada sirip ikan dilakukan dengan cara sirip ekor dan sirip dada ikan diamati kemudian dikerok lalu diletakkan pada objek glass, ditetesi aquades dan $\mathrm{NaCl}$ dan selanjutnya diamati di bawah mikroskop. Pada pemerikasaan insang, kedua belah insang diamati, kemudian dikerok lendirnya diletakkan di atas objek glass dan ditetesi $\mathrm{NaCl}$ dan aquades lalu ditutup dengan cover glass agar insangnya tidak bergerak-gerak, kemudian diamati di bawah mikroskop.

\section{Kualitas Air}

Pengukuran kualitas air dilakukan sebelum pengambilan sampel ikan yaitu suhu, pH, DO (Dissolved Oxygen) baik di 
kolam terpal pemeliharaan ikan Kapar maupun di sungai Sebangau.

\section{HASIL DAN PEMBAHASAN}

\section{Penyakit Ikan}

Ikan Kapar diambil dari sungai Sebangau yang dicoba di domestifikasi terlebih dahulu. Pemberian pakan memakai pakan alami dan diselingi dengan pakan buatan. Namun beberapa minggu kemudian, nampak ikan tidak memiliki selera makan dan permukaan tubuh ditumbuhi jamur seperti kapas. Agar tidak menyebar ke ikan yang lain, maka dilakukan isolasi terhadap ikan yang sakit seperti yang nampak pada Gambar 1.

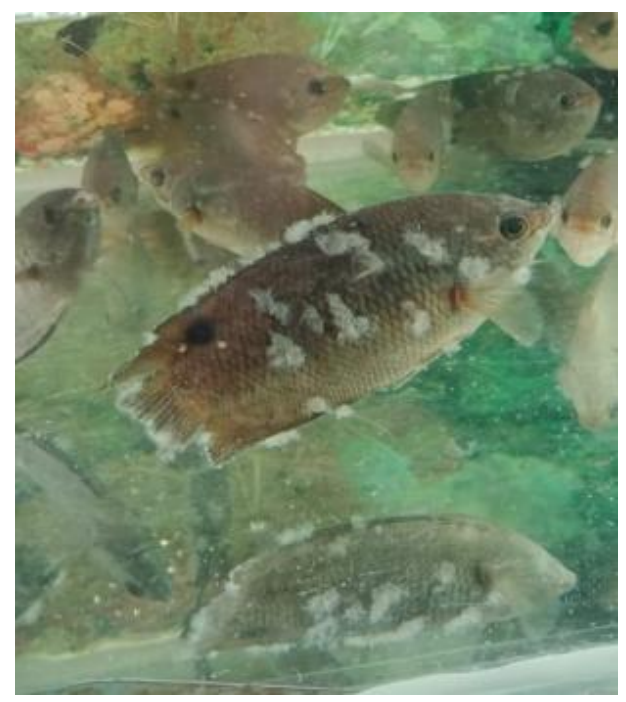

Gambar 1. Ikan Karpar yang terserang parasit

Hasil dari pengamatan yang di lakukan di lapangan gejala klinis yang terlihat pada sampel ikan kapar yang di ambil dari kolam terpal menunjukan permukaan tubuh di tumbuhi jamur seperti kapas da nada luka lecet, pada pengamatan di lapangan ikan kapar yang diduga sakit, lebih sering berenang keatas permukaan, pergerakan lambat dan berada diatas sudut atas kolam. Kumalasari (2016) menyatakan bahwa penyakit yang disebabkan oleh organisme parasit disebut penyakit. Penularan penyakit dapat terjadi melalui beberapa mekanisme, antara lain melalui kontak langsung antara ikan sakit dan ikan sehat, bangkai ikan sakit maupun melalui air, penularan ini biasanya terjadi pada satu kolam budidaya. Dari hasil yang peroleh pada sampel ikan Kapar yang diduga terserang parasit dapat di lihat pada Tabel 1.

Tabel 1. Jenis ektoparasit pada ikan Kapar (Belontia hasselti)

\begin{tabular}{|c|c|c|c|}
\hline \multirow{2}{*}{ Sampel } & \multicolumn{3}{|c|}{ Jenis ektoparasit } \\
\hline & Dactylogyrus sp & Myxobolus sp & Vortcella sp \\
\hline \multirow{3}{*}{$\begin{array}{c}\text { Ikan Kapar di kolam } \\
\text { terpal }\end{array}$} & Sirip ekor (-) & Sirip ekor (-) & Sirip ekor (-) \\
\hline & Insang (8) & Insang (2) & Insang \\
\hline & Lendir & Lendir & Lendir \\
\hline \multirow{3}{*}{$\begin{array}{c}\text { Ikan Kapar di sungai } \\
\text { Sebangau }\end{array}$} & Sirip ekor (-) & Sirip ekor (-) & Sirip ekor (-) \\
\hline & Insang $\quad(-)$ & Insang (-) & Insang (-) \\
\hline & Lendir & Lendir & Lendir \\
\hline
\end{tabular}


Berdasarkan hasil penelitian yang dilakukan baik ikan Kapar yang dipelihara maupun yang secara langsung ditangkap di sungai Sebangau didapat bahwa ikan yang terkena parasit hanyalah ikan yang berada di kolam pemeliharaan. Kemungkinan ektoparasit bukanlah bawaan dari alam namun menurut Handajani \& Samsundari (2005) bahwa hubungan antara lingkungan, ikan dan pathogen menyatakan bahwa ketika lingkungan kurang mendukung maka ikan akan stress yang menyebabkan sistem imun ikan menurun sehingga memudahkan pathogen menyerang ikan. Hal ini nampak pada ikan Kapar mengalami stress karena kemungkinan kesulitan dalam beradaptasi di tempat yang baru. Dari hasil penelitian didapat hasil bagian ikan yang terserang ektoparasit yaitu pada sirip ekor, insang dan lendir. Ektoparasit yang paling banyak menginfeksi terdapat pada insang ikan.

Jenis ektoparasit diperoleh 3 ektoparasit antara lain Dactylogyrus sp, Myxobolus sp, Vorticella sp, parasit - parasit ini bisa menyebabkan infeksi pada ikan terserang penyakit, dan mengakibatkan stres pada ikan yang akan berujung kematian pada ikan. Ektoparasit yang menyerang ikan kapar lebih dominan jenis Dactylogyrus (Gambar 2). Ektoparasit ini berbentuk seperti cacing berukuran panjang bisa mencapai $2 \mathrm{~mm}$ dan lebar tubuh $400 \mathrm{um}$ mempunyai 2 pasang eye spots pada ujung interior, dan mulut terletak dekat ujung anterior tubuh. Hal ini didukung oleh pernyataan Gusrina (2008) bahwa Dactylogyrus sp. sering menyerang pada bagian insang ikan air tawar, payau dan laut. Penyerangan dimulai dengan cacing dewasa menempel pada insang atau bagian tubuh lainnya. Ciri-ciri ikan yang terinfeksi oleh ektoparasit ini, ikan akan tampak stress, nafsu makan berkurang dan memproduksi banyak lendir. Menurut Noga (2010) beberapa gejala klinis akibat infeksi parasit antara lain ikan tampak lemah, tidak nafsu makan, pertumbuhan lambat, berenang tidak normal disertai produksi lendir yang berlebihan, sering mengapung di permukaan air, insang tampak pucat dan membengkak, sehingga operkulum terbuka. Kerusakan pada insang menyebabkan ikan sulit bernafas. Dalam keadaan serius enderum insang akan rusak dan enderum tidak tertutup dengan sempurna mengakibatkan kesulitan bernafas. Dactylogyrus sp. sangat berbahaya karena secara nyata dapat merusak filament insang sehingga sangat sulit dikendalikan.

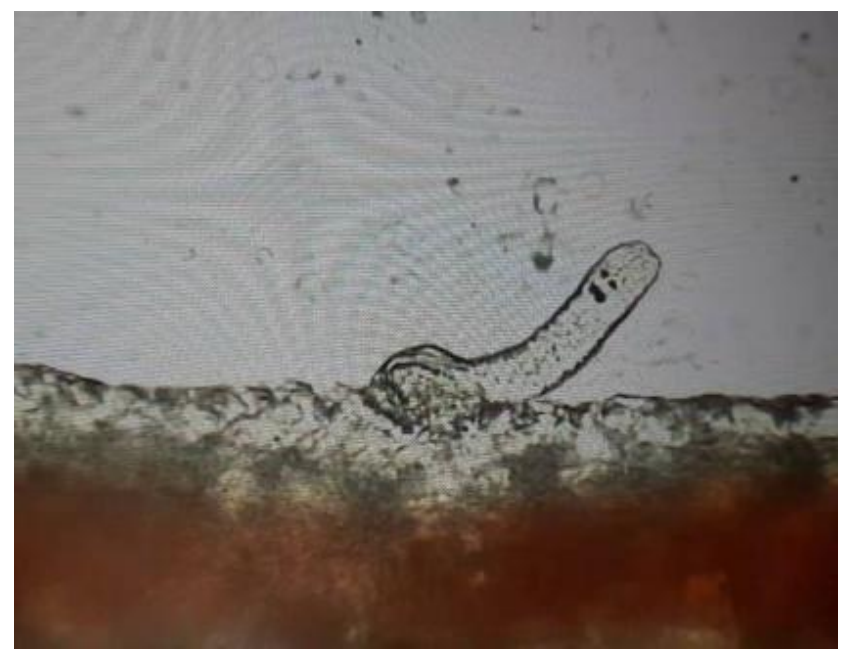

Gambar 2. Dactylogyrus sp. 
Pada pengamatan yang lain dibagian insang ditemukan ektoparasit Myxobolus sp (Gambar 3). Myxobolus sp. ditemukan menyerang insang, badan dan ekor ikan. Myxobolus sp. yang menginfeksi insang akan sangat menggangu pernapasan ikan. Menurut Dewi (2010) parasit ini membentuk kista pada lembar insang ikan, sehingga akan menghalangi proses penyerapan oksigen.

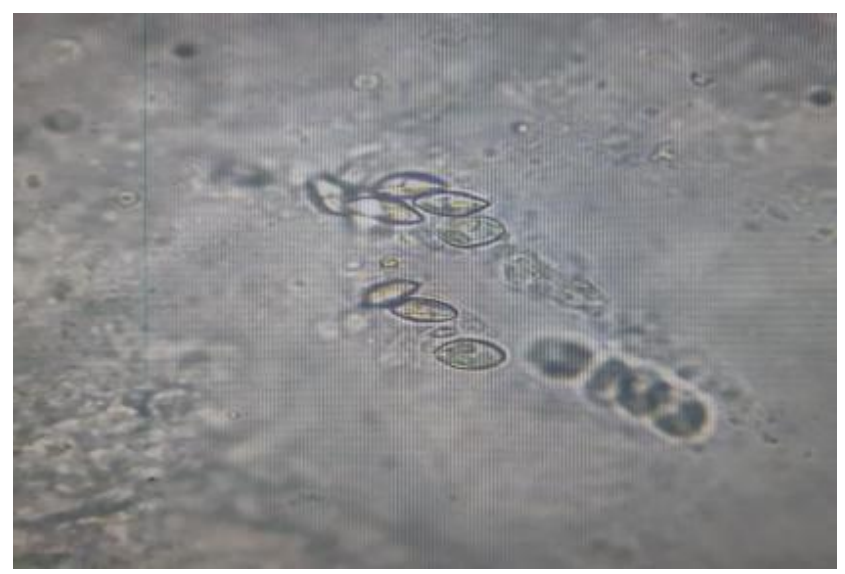

Gambar 3. Myxobolus sp

Pada bagian insang dan lendir juga ditemukan ektoparasit jenis Vorticellla $\mathrm{sp}$ (Gambar 4). Vorticellla sp. merupakan ektoparasit yang hidup secara soliter dan menempel. Ektoparasit ini pada saat ditemukan berbentuk seperti lonceng dengan tangkai satu pipih dan silindris. Vorticella sp. yang ditemukan berwarna transparan, tangkai yang panjang dan tidak berkoloni. Menurut Lukrejo (2008) bahwa bentuk ektoparasit ini hampir menyerupai Epistylis sp., namun Epistylis sp. hidup berkoloni sedangkan Vorticella sp. bersifat soliter. Pada saat penelitian ada banyak ektoparasit Vorticella sp yang masih hidup (Gambar 4). Gejala yang terinfeksi jenis ektoparasit ini akan kelihatan tubuh seperti berlumut,dengan warna kecoklatan yang diakibatkan oleh penempelan protozoa jenis Vorticella sp. ini. Protozoa ini juga sering menempel pada insang sehingga kelihatan berwarna kecoklatan dan pada akhirnya akan mengakibatkan warna insang menjadi kehitaman.

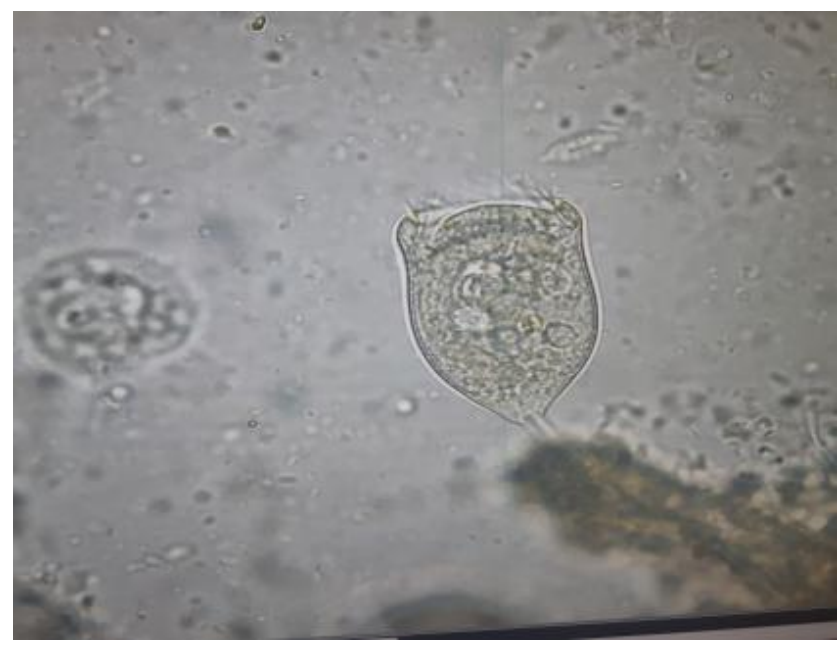

Gambar 4. Vorticella sp. 


\section{Kualitas Air}

Kondisi lingkungan perairan merupakan faktor yang dapat mempengaruhi kehidupan ikan pada habitatnya. Parameter kualitas air yang diukur adalah suhu, $\mathrm{pH}$, dan DO. Kualitas air diambil sebelum pengamatan sampel ikan dapat terlihat pada Tabel 2.

Tabel 2. Kualitas air pada pada kolam dan sungai Sebangau

\begin{tabular}{cccc}
\hline \multirow{2}{*}{ Lokasi air sampel } & \multicolumn{3}{c}{ Kualitas Air } \\
\cline { 2 - 4 } & Suhu $\left({ }^{\circ} \mathrm{C}\right)$ & $\mathrm{pH}$ & DO $(\mathrm{mg} / \mathrm{l})$ \\
\hline Kolam Terpal & 27 & 5 & 3 \\
Perairan Sebangau & 28 & 5 & 4 \\
\hline
\end{tabular}

Suhu baik di kolam terpal maupun sungai sebangau tidak berbeda jauh yaitu berkisar antara $27-28{ }^{\circ} \mathrm{C}$. Kondisi suhu tersebut menunjukkan kondisi yang mendukung pertumbuhan ikan Kapar. Menurut Handajani \& Samsundari (2005) bahwa respon kekebalan pada ikan tergantung pada suhu, misalnya ikan Karper tidak bisa memproduksi antibodi pada suhu dibawah $10{ }^{\circ} \mathrm{C}$. Selanjutnya menurut Huet (1971) bahwa pertumbuhan meningkat seiring dengan meningkatnya suhu sampai mencapai titik maksimum $\left(30^{\circ} \mathrm{C}\right)$.

Kisaran pH pada kedua lokasi tersebut berkisar 5. Menurut Hasanah et al. (2019) bahwa $\mathrm{pH}$ dengan kisaran 5 menunjukkan tingkat kelangsungan hidup (SR) yang tinggi dibandingkan $\mathrm{pH}$ diatasnya. Hal tersebut dikarenakan pada perlakuan pH 5 merupakan $\mathrm{pH}$ yang sesuai dengan habitat asli. Sehingga ikan Kapar pada perlakuan ini tahan terhadap $\mathrm{pH}$ air yang rendah dikarenakan, ikan Kapar memiliki alat pernapasan tambahan dan sisik lebih keras. Pada $\mathrm{pH}$ rendah seperti 5, untuk sebagian ikan yang tidak mampu beradaptasi maka dapat menyebabkan kematian pada ikan.

Untuk kisaran DO pada 2 lokasi menunjukkan kisaran antara 3-4 mg/l. Menurut Boyd (1982) dalam Yuli (2008), bahwa kandungan oksigen $<1 \mathrm{mg} / \mathrm{L}^{-1}$ bersifat Lethal bagi ikan apabila terpapar dalam waktu beberapa jam dalam air yang mengandung oksigen 1-5 mg/ $\mathrm{L}^{-1}$ ikan akan bertahan namun pertumbuhan lambat, sedangkan pada air mengandung oksigen $>5$ $\mathrm{mg} / \mathrm{L}^{-1}$ ikan dapat hidup dan tumbuh secara normal. Kisaran DO dikolam lebih rendah dibandingkan di sungai Sebangau meskipun sudah ada tambahan aerasi. Kemungkinan hal inilah yang menyebabkan ikan stress meskipun sebenarnya ikan Kapar memiliki daya adaptasi yang tinggi terhadap oksigen karena memiliki alat pernafasan tambahan.

\section{KESIMPULAN}

Hasil penelitian yang dilakukan baik ikan Kapar yang dipelihara maupun yang secara langsung ditangkap di sungai Sebangau didapat bahwa ikan yang terkena parasit hanyalah ikan yang berada di kolam pemeliharaan. Bagian ikan yang terserang ektoparasit yaitu pada sirip ekor, insang dan lendir. Ektoparasit yang paling banyak menginfeksi terdapat pada insang ikan. Jenis ektoparasit diperoleh 3 ektoparasit antara lain Dactylogyrus sp, Myxobolus sp, Vorticella sp. Namun Ektoparasit yang menyerang ikan Kapar lebih dominan jenis Dactylogyrus.

Suhu baik di kolam terpal maupun sungai Sebangau tidak berbeda jauh yaitu berkisar antara $27-28{ }^{\circ} \mathrm{C}$. Kisaran $\mathrm{pH}$ pada kedua lokasi tersebut berkisar 5. Hal ini menunjukan kisaran suhu dan $\mathrm{pH}$ masih normal untuk kehidupan ikan Kapar. Namun Kisaran DO dikolam terpal lebih rendah yaitu berkisar $3 \mathrm{mg} / \mathrm{l}$ dibandingkan di sungai Sebangau yaitu berkisar $4 \mathrm{mg} / \mathrm{l}$ meskipun 
sudah ada tambahan aerasi, kemungkinan hal inilah yang menyebabkan ikan stress.

\section{DAFTAR PUSTAKA}

Akbar, J. 2011. Identifikasi Parasit pada Ikan Betok (Anabas testudieus). Journal of Bioscientiae. 8 (2) : 36-45.

Daulae, A.S., Suryanto, D., Desrita. 2018. Identifikasi Jenis-Jenis Ektoparasit pada Ikan Lele Dumbo (Clarias gariepinus). Jurnal Aquacoastmarine $6(1): 123-132$.

Daulay, A.A., Rumondang, Puspitasari, D. 2018. Pengaruh Pemberian Pakan Alami Terhadap Pertumbuhan dan Kelangsungan Hidup Larva Ikan Selinca (Belontia hasselti). Prosiding Seminar Nasional Multidisiplin Ilmu Universitas Asahan. Tema : "Strategi Membangun Penelitian Terapan yang Bersinergi dengan Dunia Industri, Pertanian dan Pendidikan dalam Meningkatkan Daya Saing Global”. Kisaran.

Handajani, H., Samsundari, S. 2005. Parasit \& Penyakit Ikan. Malang : Universitas Muhammadiyah Malang.

Harlina, H., Hadijah S., Kamaruddin., Nurhidayah, Nurwahyudin. 2019. Prevalensi dan Intensitas Ektoparasit pada Ikan Nila (Oreocromis niloticus) yang Diberi Pakan Bungkil Kelapa Hasil Fermentasi dalam Wadah Terkontrol. Journal of Indonesian Tropical Fisheries 2 (2) : 192-205.

Hasanah, N., Robin, Prasetiyono, E. 2019. Tingkat Kelangsungan Hidup dan Kinerja Pertumbuhan Ikan Selincah (Belontia hasselti) dengan $\mathrm{pH}$ Berbeda. Jurnal Akuakultur Rawa Indonesia 7 (2) : 99-112.
Kadarsah, A., Muhamat., Hidayaturrahmah. 2017. Keanekaragaman Jenis dan Prevalensi Ektoparasit pada Lima Jenis Ikan Komersial di Desa Sungai Batang Kecamatan Martapura Barat. Bioscientiae 14 (1) : 1-8.

Khumaidi, A., Hidayat, A. 2018. Identifikasi Penyebab Kematian Massal Ikan Gurami (Osphronemus gouramy) di Sentra Budidaya Ikan Gurami, Desa Beji, Kecamatan Kedung Banteng, Kabupaten Banyumas, Jawa Tengah. Journal of Aquaculture Science Oktober 3 (2): 145-153.

Manurung, U.N., Gaghenggang, F. 2016. Identifikasi dan Prevalensi Ektoparasit pada Ikan Nila (Oreochromis niloticus) di Kolam Budidaya Kampung Hiung, Kecamatan Manganitu, Kabupaten Kepulauan Sangihe. Budidaya Perairan 4 (2) : 26-30.

Noga, E.J. 2010. Fish Disease Diagnosis and Treatment. 2nd Edition. USA : Wiley- Balckwell.

Nurekawati, A.D., Mahasri, G., Yunus, M. 2016. Identifikasi Myxobolus sp. Pada Famili Cyprinidae dengan Metode Molokuler di Provinsi Jawa Timur dan Jawa Tengah. Jurnal Biosains Pascasarjana 18 (2).

Prihartini, N. C., Alfiyah A. 2017. Myxosporeasis in Koi (Cyprinus carpio). Samakia Jurnal Ilmu Perikanan 8 (1) : 6-10.

Salam, B., Hidayati, D. 2017. Prevalensi dan Intensitas Ektoparasit pada Ikan Gabus (Channa striata) dari Tangkapan Alam dan Budidaya. Jurnal Sains dan Seni ITS 6 (1). 
Sudaryatma, P.E., Eriawati N.N., Panjaitan I.F., Sunarsih N.L. 2013. Histopatologi Insang Ikan Lele (Clarias bathracus) yang Terinfestasi Dactylogyrus sp. Acta Veterinaria Indonesiana 1 (2) : 75-80.

Welsiana, S., Yulintine, L., Septiani, T., Wulandari, L., Trisliana, Yurenfrie, Limin, SH., Haraguchi, A. 2012. Composition of Macrozoobenthos
Community in The Sebangau River Basin, Central Kalimantan, Indonesia. Tropics 21 (4) : 127 136.

Yuli, A. 2008. Kinerja Pertumbuhan Ikan Gurame pada Media Bersalinitas 3 ppt dengan Paparan Media Listrik. [Skripsi]. Bogor : Institut Pertanian Bogor. 